\title{
A new Amphisbaena (Squamata: Amphisbaenidae) from southern Espinhaço Range, southeastern Brazil
}

\author{
HENRIQUE C. COSTA $^{1}$, FLÁVIA C. RESENDE ${ }^{2}$, MAURO TEIXEIRA Jr. ${ }^{3}$, \\ FRANCISCO DAL VECHIO ${ }^{3}$ and CINARA A. CLEMENTE ${ }^{1}$ \\ ${ }^{1}$ Programa de Pós-Graduação em Zoologia, Instituto de Ciências Biológicas, \\ Universidade Federal de Minas Gerais, Departamento de Zoologia, Laboratório de Herpetologia, \\ Av. Antônio Carlos, 6627, Pampulha, 31270-901 Belo Horizonte, MG, Brasil \\ ${ }^{2}$ Fundação Ezequiel Dias, Unidade de Coleções Científicas e Popularização da Ciência, \\ Rua Conde Pereira Carneiro, 80, Gameleira, 30510-010 Belo Horizonte, MG, Brasil \\ ${ }^{3}$ Instituto de Biociências, Departamento de Zoologia, Universidade de São Paulo, \\ Laboratório de Herpetologia, Rua do Matão, 14, Butantã, 05508-090 São Paulo, SP, Brasil \\ Manuscript received on February 20, 2014; accepted for publication on November 25, 2014
}

\begin{abstract}
A new species of Amphisbaena is described from a semi-deciduous forest in Conceição do Mato Dentro, southern Espinhaço Range, Minas Gerais, Brazil. The following combined characters can diagnose the new species from all congeners: head round-shaped; two or three precloacal pores sequentially arranged; 190-199 body annuli; 2-3 lateral annuli; 23-25 caudal annuli; autotomy sites on caudal annuli 7-9; 12-14 dorsal segments on midbody annulus; $14-16$ ventral segments on midbody annulus; three supralabials; three infralabials; postmalar row present or absent; dorsum light brown, with cream intersegmental sutures; venter cream. To date, the new species is known only from the Espinhaço Range, highlighting the importance of conservation actions for these mountains.
\end{abstract}

Key words: Minas Gerais, taxonomy, Amphisbaenia, Fossorial reptile.

\section{INTRODUCTION}

Amphisbaenia is a group of annulate squamates adapted to fossorial life, with about 190 valid extant species (Pianka and Vitt 2003, Uetz and Hošek 2014), widely distributed in South America, Caribbean, Mexico, Florida, eastern and sub-Saharan Africa, Morocco, Algeria and Turkey, besides the Arabian and Iberian peninsulas (Pianka and Vitt 2003, Vidal et al. 2008). The monophyly of Amphisbaenia is

Correspondence to: Henrique Caldeira Costa

E-mail:ccostah@gmail.com well supported (Kearney 2003, Macey et al. 2004), but its placement within Squamata is still uncertain (e.g. Kearney 2003, Pianka and Vitt 2003, Kearney and Stuart 2004, Macey et al. 2004, Conrad 2008, Gauthier et al. 2012, Pyron et al. 2013). Recently, the generic status of the South America amphisbaenids suffered a significant taxonomic rearrangement, with five genus (Anops, Aulura, Bronia, Cercolophia and Leposternon) synonymized into Amphisbaena (Mott and Vieites 2009), a condition still not fully adopted (e.g. Ribeiro et al. 2012). 
A total of 72 species of amphisbaenids are known to occur in Brazil, however, the group's biodiversity is still poorly known, with many taxa discovered in the last 15 years (Costa and Bérnils 2014). Since the year 2000, 19 new amphisbaenid species were described in Brazil, representing 26\% of its current richness. Besides the fossorial habits making amphisbaenids hard to find and collect, many Brazilian species named in the last decades were discovered during environmental impact assessments and wildlife rescues (see Ribeiro et al. 2008 for a short review, Ribeiro et al. 2012, Roberto et al. 2014, Teixeira et al. 2014). During an environmental impact assessment between August 2009 and May 2010 in Conceição do Mato Dentro, southern Espinhaço Range, state of Minas Gerais, southeastern Brazil, specimens of a small Amphisbaena were collected, which we concluded to belong to a new species described below.

\section{MATERIALS AND METHODS}

Specimens were found and collected by hand, during deforestation activities for the installation of a slurry pipeline in Conceição do Mato Dentro, state of Minas Gerais, southeastern Brazil. Scale nomenclature follows Gans and Alexander (1962) and Teixeira et al. (2014); morphometric measures were taken to the nearest $0.1 \mathrm{~mm}$ with a caliper, except for the snout-vent and tail lengths, which were measured with a flexible ruler to the nearest $1.0 \mathrm{~mm}$. Body slenderness proportion (BSP) (snout-vent length / head width) follows Pinna et al. (2014). Specimens were collected under permit \#400/2009 NUFAS/MG provided by Instituto Brasileiro do Meio Ambiente e Recursos Naturais Renováveis (IBAMA) and deposited in the collections of Fundação Ezequiel Dias (FUNED) and Universidade Federal de Minas Gerais (UFMG), Belo Horizonte, Minas Gerais, Brazil. Comparative data were taken from literature and specimens in the herpetological collections of Universidade Federal do Rio Grande (CHFURG),
Museu de Zoologia da Universidade de São Paulo (MZUSP) and Miguel Trefaut Rodrigues collection (MTR) (Table SI - Supplementary Material; Appendix).

TheZooBankLifeScienceIdentifier(LSID) ofthis publication is: urn:lsid:zoobank.org:pub:FD9F4C2AE6CF-4B33-B805-46DD1317702D.

\section{RESULTS}

Amphisbaena metallurga SP. NOV.

ZooBank Life Science Identifier (LSID) urn:1sid:zoobank.org:act:E74873DF-8074-4E39B23F-1FAC0AD21C46.

Holotype. FUNED 2943 (Fig. 1A-G), collected in August 2009 or May 2010 (no specific date available), by Dimitri Lima Gouvêa and Sarita Pimenta de Oliveira.

Type-locality. Brazil: Minas Gerais: Conceição do Mato Dentro, semi-deciduous seasonal forest, ca. $18^{\circ} 54^{\prime} \mathrm{S}, 43^{\circ} 25^{\prime} \mathrm{W}, 700$ m elevation, southern Espinhaço Range (Fig. 2).

Paratypes. FUNED 2940-2942, 2944, 2945, 2947-2949, 2951-2960, UFMG 2080 (ex. FUNED 2946), 2081 (ex FUNED 2950), collected in August 2009 or May 2010 (no specific date available) by Dimitri Lima Gouvêa and Sarita Pimenta de Oliveira. All paratypes from the type-locality.

Diagnosis. Amphisbaena metallurga sp. nov. is diagnosed by the following combination of characters: (1) head round-shaped; (2) two or three precloacal pores sequentially arranged; (3) 190-199 body annuli; (4) 2-3 lateral annuli; (5) 23-25 caudal annuli; (6) autotomy plan on $7^{\text {th }}$ $9^{\text {th }}$ caudal annulus; (7) 12-14 dorsal segments on midbody annulus; (8) 14-16 ventral segments on midbody annulus; (9) three supralabials; (10) three infralabials; (11) postmalar row usually present; (12) body slenderness proportion from 32.6 to 38.3 ; (13) dorsum of preserved specimens light brown, with cream intersegmental sutures; (14) venter of preserved specimens cream colored. 


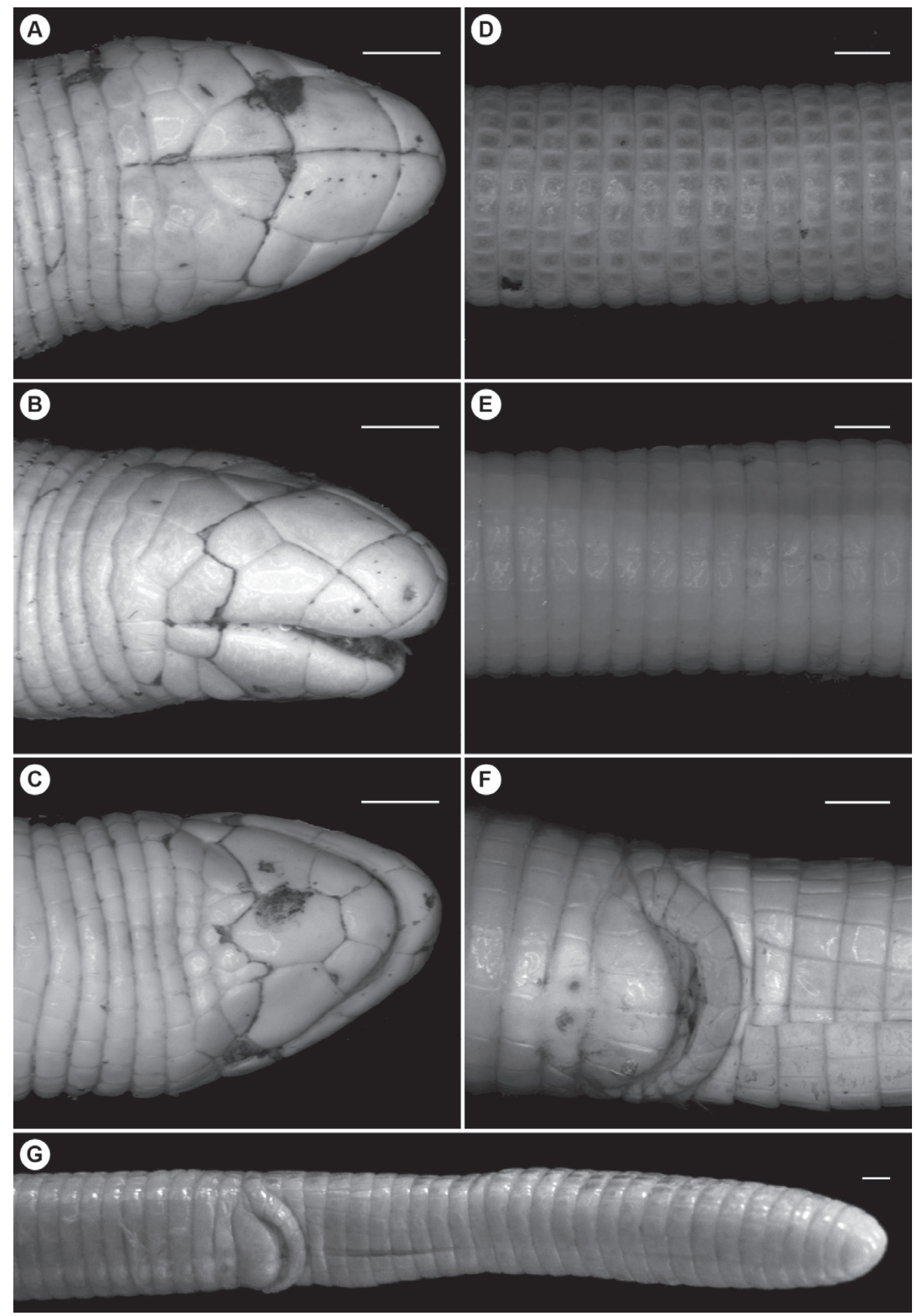

Figure 1 - Holotype of Amphisbaena metallurga sp. nov. (FUNED 2943). A) head in dorsal view; B) head in lateral view; C) head in ventral view; D) detail of body dorsum; E) detail of body venter F) detail of cloacal region; G) ventral view of cloaca and tail (an incision at tail base was made to sex the specimen). Scale bars $=1 \mathrm{~mm}$. Photographs by Bárbara F. Zaidan $(\mathrm{A}-\mathrm{F})$ and Flávia C. Resende $(\mathrm{G})$. 


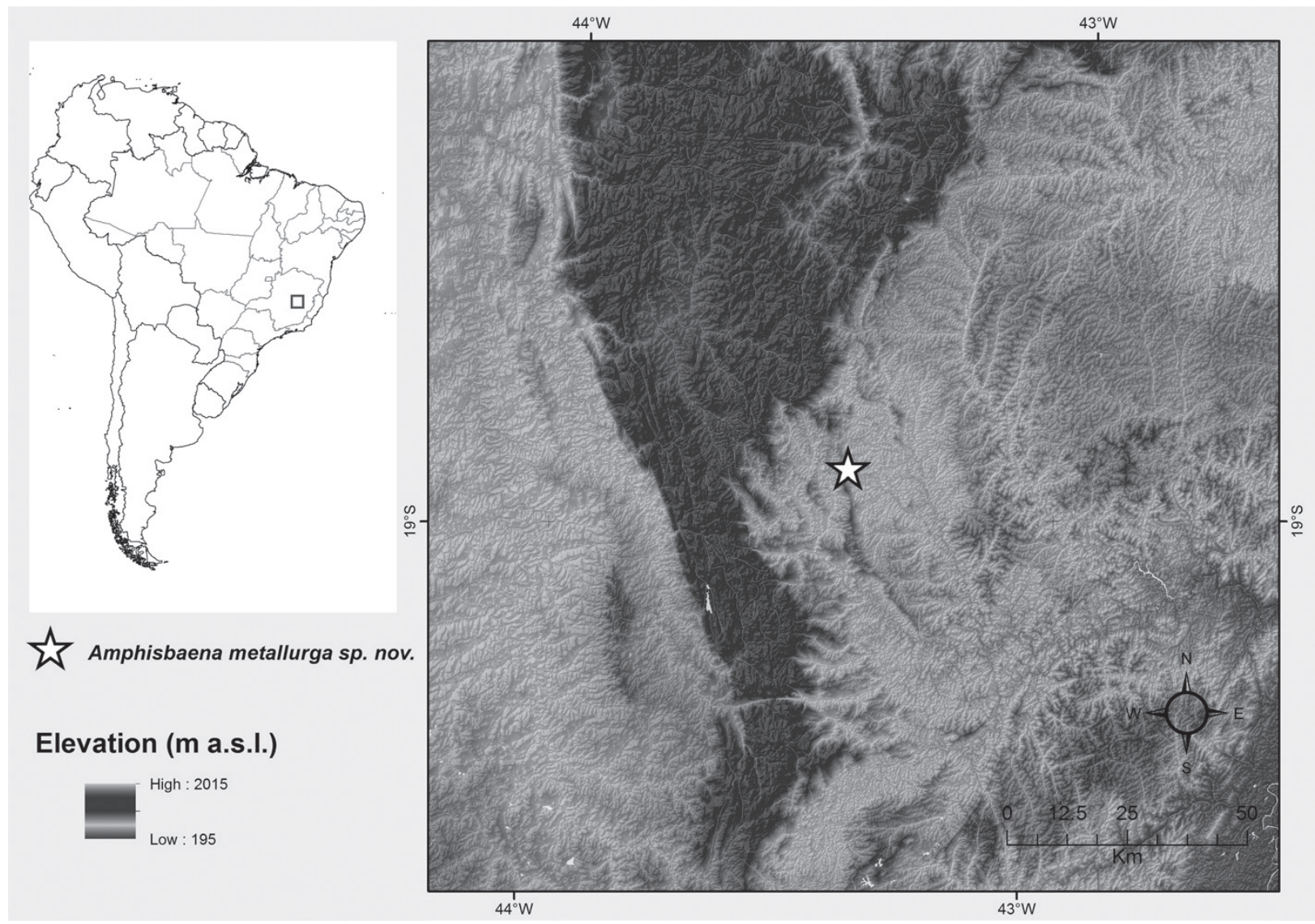

Figure 2 - Map representing the type locality of Amphisbaena metallurga sp. nov. (FUNED 2943) in Conceição do Mato Dentro, state of Minas Gerais, Brazil.

Comparison with other species. The presence of two or three precloacal pores makes Amphisbaena metallurga sp. nov. readily distinguishable from all South American congeners with the exception of A. absaberi, A. anaemariae, A. anomala, A. angustifrons, A. bilabialata, A. bolivica, A. brevis, A. caiari, A. camura, A.carli, A. cerradensis, A. crisae, A. cuiabana, A. darwinii, A. dubia, A. heterozonata, A. hiata, A. kisteumacheri, A. leeseri, A. lumbricalis, A. maxima, A. miringoera, A. mitchelli, A. neglecta, A. persephone, A. polystega, $A$. roberti and $A$. silvestrii. Among these species (characters inside parentheses), the rounded head easily distinguishes Amphisbaena metallurga sp. nov. from $A$. anomala, $A$. cerradensis, $A$. kisteumacheri, A. maxima, A. polystega (head shovel-shaped) and A. bilabialata (head keel- shaped). Therefore, these six species are excluded from following comparisons.

The rounded tail distinguishes Amphisbaena metallurga sp. nov. from $A$. trachura (caudal tip tuberculate), A. absaberi, A. cuiabana and A. roberti (tail with a terminal vertical keel). The rostral without median contact with prefrontals distinguishes Amphisbaena metallurga sp. nov. from A. carli (rostral in broad contact with prefrontals). The presence of precloacal pores arranged in sequence distinguishes Amphisbaena metallurga sp. nov. from A. absaberi, $A$. carli and $A$. hiata (precloacal pores separated from each other by segments).

The presence of 190-199 body annuli distinguishes Amphisbaena metallurga sp. nov. from A. absaberi (239-242), A. anaemaeriae 
(156-170), A. bolivica (200-231), A. brevis (139), A. caiari (233-250), A. carli (221-248), A. crisae (180-185), A. cuiabana (283-320), A. dubia (211231), A. hiata (202-213), A. leeseri (216-249), A. lumbricalis (225-247), A. miringoera (250-264), A. mitchelli (203-220), A. neglecta (151-161), A. persephone (230-241) and A. roberti (232-265). The presence of 23-25 caudal annuli distinguishes Amphisbaena metallurga sp. nov. from $A$. absaberi (14-15), A. anaemaeriae (18-20), A. angustifrons (12-18), A. brevis (9), A. camura (14-19), A. carli (10-14), A. crisae (20-22), A. cuiabana (17-21), A. dubia (13-18), A. heterozonata (13-18), A. hiata (17-19), A. leeseri (14-19), A. mitchelli (2629), A. neglecta (14-16), A. persephone (19-22) and $A$. roberti (17-20). Autotomy in annuli 7-9 distinguishes Amphisbaena metallurga sp. nov. from A. absaberi (5-6), A. anaemaeriae (3-5), A. angustifrons (autotomy absent), A. bolivica (3-5), A. camura (3-5), A. carli (autotomy absent), $A$. crisae (4-6), A. dubia (autotomy absent), and $A$. neglecta (4-6).

The presence of 12-14 dorsal segments distinguishes Amphisbaena metallurga sp. nov. from A. brevis (18) and A. caiari (10). The number of both dorsal and ventral segments (12-14 / 1416) distinguishes the new species from $A$. absaberi (16-19/ 17-20), A. angustifrons (20-31/21-30), A. bolivica (27-38/26-36), A. camura (28-42/ 29-46), A. carli (20-23 / 18-23), A. crisae (10/ $10)$ and $A$. hiata (16-18/18-22). A summary of morphological characters for two-pored and threepored Amphisbaena is provided in Table SI.

Despite the differences above mentioned, the new species is more similar to Amphisbaena darwinii, A. heterozonata, A. prunicolor, A. trachura and $A$. silvestrii in the traditional meristic data, but can be further distinguished by the following characters: From A. prunicolor by the number of precloacal pores (two or three in $A$. metallurga sp. nov. and four in A. prunicolor), and color pattern (light brown dorsally and cream ventrally in A. metallurga sp. nov., and dark brown dorsally and ventrally (sometimes checkered) in $A$. prunicolor) (see Perez et al. 2012 for pictures of A. prunicolor). From A. silvestrii the new species can be distinguished by the shape of the third infralabial (as long as the third supralabial in $A$. metallurga sp. nov. and about 1.5-2 times longer than the third supralabial in $A$. silvestrii), and color pattern (dark brown dorsally and ventrally in $A$. silvestrii). Additionally, A. metallurga sp. nov. usually presents a postmalar row (see Table I for exceptions), absent in $A$. silvestrii.

Specimens of $A$. darwinii, A. heterozonata and $A$. trachura usually present four precloacal pores, but some A. darwinii and A. heterozonata have two or three and some $A$. trachura have three pores, as in $A$. metallurga sp. nov. In this case, $A$. metallurga sp. nov. can be distinguished from A. darwinii, A. heterozonata and A. trachura by the color pattern. Dorsally, preserved specimens of those three species are dark brown, while $A$. metallurga sp. nov. is light brown. Additionally, $A$. trachura presents a tuberculate caudal tip, absent in specimens of the new species, and A. heterozonata has a fewer number of caudal annuli (see above).

Description of the holotype. A small male amphisbaenian (snout-vent length $178 \mathrm{~mm}$; caudal length $30 \mathrm{~mm}$; BSP 36.5); head short (7.0 mm, 3.9\% of snout-vent length), rounded and hardly distinct from the neck; rostrum rounded, projecting beyond the lower jaw. Rostral triangular, barely visible in dorsal view, in broad contact with nasals laterally and in narrow contact with first supralabial, lateroposteriorly. One pair of quadrangular nasals, with a middorsal suture of $1.14 \mathrm{~mm}(15.7 \%$ of head length), in broad contact with the rostral anteriorly, first supralabial laterally and prefrontals posteriorly, and in point contact with second supralabials. Nostrils placed in the antero-lateral portion of nasal shields. A pair of trapezoid prefrontals, with a middorsal suture of $2.17 \mathrm{~mm}$ (28.6\% of head length), in broad contact with nasals anteriorly, in 
point contact with first supralabial latero-anteriorly, broad contact with second supralabial laterally, ocular latero-posteriorly, and frontals posteriorly. Right prefrontal with a point contact with right postocular. A pair of triangular frontals, converging posteriorly, with a middorsal suture of $2.04 \mathrm{~mm}$ (28.6\% of head length), in point contact with dorsal angle of oculars laterally, in contact with prefrontals anteriorly, postoculars latero-posteriorly, and parietals posteriorly. Two pentagonal parietal shields, wider than long, with a middorsal suture of $0.7 \mathrm{~mm}$ ( $10 \%$ of head length), in broad contact with postocular latero-anteriorly, frontal anteriorly, second body annulus posteriorly, and other scales of first body annulus latero-posteriorly. Ocular pentagonal, in broad contact with second and third supralabials ventrally, prefrontal and postocular dorsally, in narrow contact with temporal posteriorly, and in point contact with frontals. Eye barely visible in anterior corner of ocular. Temporals quadrangular, contacting ocular anteriorly, postocular dorsally, third supralabial ventro-anteriorly, postsupralabial ventroposteriorly, and first body annulus dorso-posteriorly.

Three supralabials, first triangular, longer than wide, and lower than other supralabials, contacting narrowly the rostral latero-anteriorly, contacting broadly the nasal dorsally, second supralabial posteriorly, and in point contact with prefrontal. Second supralabial pentagonal, highest and longest than others, in broad contact with the prefrontal dorsally, ocular dorso-posteriorly, third supralabial posteriorly, and in point contact with nasal. Third supralabial pentagonal, higher than wide, and narrower than other supralabials, in broad contact with postsupralabial posteriorly, temporal dorsoposteriorly, second supralabial anteriorly and ocular dorso-anteriorly.

Mental shield trapezoidal, contacting postmental posteriorly and first infralabials laterally. Postmental heptagonal, elongated, longer than wide, contacting postgenials posteriorly, second infralabials laterally, first infralabials latero-anteriorly, and mental anteriorly. One irregular row of postgenials, with eight scales of different sizes, in contact with postmental, second infralabials, malars, and postmalar row. Postmalar row with seven shields. Three infralabias, first trapezoid, the second pentagonal and largest, third rectangular, the smallest and wider than high. First infralabial contacting mental anteriorly, postmental laterally, and second infralabial posteriorly; second infralabial contacts postmental laterally, postgenials latero-posteriorly, malar and third infralabial posteriorly; third infralabial contacting postinfralabial posteriorly, malar latero-anteriorly, and first shield of postmalar row latero-posteriorly.

Dorsally the first body annulus includes postsupralabials, parietals, and two scales between them on each side. Ventrally it includes the postinfralabials and segments between them. There are 192 body annuli, with 12 quadrangular dorsal segments and 14 quadrangular ventral segments (central ventral segments wider than the others); dorsal and ventral sulci absent and lateral sulci visible from $17^{\text {th }}$ body annulus to cloacal shields. Two precloacal pores are visible, sequentially arranged in posterior portion of the last ventral annulus. The holotype also presents six precloacal scales and 14 postcloacal scales, three lateral annuli, 25 caudal annuli, with autotomy plan in the ninth caudal annulus, and tip of tail not compressed into a vertical keel.

In preservative, dorsal color is light brown; center of segments is darker, with cream intersegmental sutures. Venter uniformly cream colored. Head uniformly cream. In life, head uniformly light pink, dorsal segments brown with pink intersegmental sutures, and ventral segments uniformly light pink (CAC pers. obs.).

Intraspecific variation. Meristic and morphometric variations of the type-series are present in Table I. Some additional variation in cephalic shields and scales were observed. There is no contact between temporal and ocular of the left side in UFMG 2080, FUNED 2954, FUNED 
TABLE I

Meristic and morphometric variations (in millimeters) of the type-series of Amphisbaena metallurga sp. nov. SVL = snout-vent length; $T L=$ tail length; $H W=$ head width; $B S P=$ body slenderness proportion $(\mathrm{SVL} / \mathrm{HW})$; $\mathrm{POR}=$ number of precloacal pores; $\mathrm{PeC}=$ number of precloacal scales on cloacal shield; $\mathrm{PoC}=$ number of postcloacal scales on cloacal shield; $\mathbf{B A}=$ number of midbody annuli; $\mathbf{L A}=$ number of lateral annuli; $\mathbf{C A}=$ number of caudal annuli; AA = autotomy annulus; DS = number of dorsal segments; VS = number of ventral segments; PMR = number of scales in postmalar row; GEN $=$ number of genial scales $\left(\operatorname{scales}\right.$ of $1^{\text {st }}$ row + of $2^{\text {nd }}$ row). Specimens with a + symbol after SVL have only the anterior part of body.

\begin{tabular}{|c|c|c|c|c|c|c|c|c|c|c|c|c|c|c|c|c|}
\hline Specimen & Sex & SVL & TL & HW & BSP & POR & $\mathrm{PeC}$ & PoC & BA & LA & CA & $\mathbf{A A}$ & DS & VS & PRM & GEN \\
\hline $\begin{array}{l}\text { FUNED } 2943 \\
\text { (holotype) }\end{array}$ & $\mathrm{M}$ & 178 & 30 & 4.9 & 36.5 & 2 & 6 & 14 & 192 & 3 & 25 & 9 & 12 & 14 & 7 & 8 \\
\hline FUNED 2940 & $\mathrm{~F}$ & 167 & 28 & 4.7 & 35.5 & 3 & 6 & 13 & 193 & 3 & 24 & 8 & 12 & 14 & $0^{\#}$ & $3+4$ \\
\hline FUNED 2941 & $\mathrm{~F}$ & 155 & $10+$ & 4.5 & 34.4 & 2 & 6 & 10 & 196 & 3 & $8+$ & 8 & 12 & 14 & 7 & $2+5$ \\
\hline FUNED 2942 & $\mathrm{~F}$ & 171 & $7+$ & 4.6 & 37.1 & 2 & 6 & 14 & 194 & 3 & $8+$ & 8 & 12 & 14 & 7 & $2+5$ \\
\hline FUNED 2944 & $\mathrm{~F}$ & 174 & 26 & 4.7 & 37.0 & 2 & 6 & 12 & 199 & 3 & 23 & 8 & 12 & 16 & 7 & $2+3$ \\
\hline FUNED 2945 & $?$ & $140+$ & - & 4.9 & - & - & - & - & $165+$ & - & - & - & 13 & 14 & 8 & $2+8$ \\
\hline UFMG 2080 & $\mathrm{~F}$ & 175 & 30 & 4.7 & 37.2 & 2 & 6 & 14 & 193 & 3 & 24 & 8 & 12 & 14 & 7 & 2 \\
\hline FUNED 2947 & $\mathrm{~F}$ & 152 & $10+$ & 4.4 & 34.5 & 2 & 6 & 15 & 192 & 3 & $8+$ & 8 & 14 & 15 & 7 & 7 \\
\hline FUNED 2948 & $?$ & $105+$ & - & 4.2 & - & - & - & - & $113+$ & - & - & - & 13 & 16 & 7 & $2+5$ \\
\hline FUNED 2949 & $?$ & $150+$ & - & 4.4 & - & - & - & - & $114+$ & - & - & - & 14 & 14 & $0^{\#}$ & $2+5$ \\
\hline UFMG 2081 & $\mathrm{~F}$ & 160 & $8+$ & 4.7 & 34.0 & 2 & 6 & 9 & 195 & 2 & $9+$ & 9 & 14 & 15 & 7 & $2+5$ \\
\hline FUNED 2951 & $\mathrm{~F}$ & 157 & $9+$ & 4.1 & 38.3 & 3 & 6 & 10 & 190 & 3 & $8+$ & 8 & 12 & 14 & 6 & 3 \\
\hline FUNED 2952 & $?$ & $115+$ & - & 4.6 & - & - & - & - & $133+$ & - & - & - & 12 & 14 & 6 & $2+5$ \\
\hline FUNED 2953 & $?$ & $85+$ & - & 4.7 & - & - & - & - & $94+$ & - & - & - & 12 & 14 & 7 & $3+4$ \\
\hline FUNED 2954 & $\mathrm{M}$ & 179 & $10+$ & 5.0 & 35.8 & 2 & 6 & 15 & 193 & 3 & $8+$ & 8 & 14 & 16 & 7 & $2+4$ \\
\hline FUNED 2955 & $?$ & 135 & 22 & 3.9 & 34.6 & 2 & 6 & 16 & 199 & 2 & 24 & 8 & 12 & 14 & 7 & 4 \\
\hline FUNED 2956 & $?$ & 101 & 15 & 3.1 & 32.6 & 2 & 6 & 13 & 194 & 3 & 23 & 7 & 12 & 14 & 6 & 4 \\
\hline FUNED 2957 & $\mathrm{~F}$ & 154 & $8+$ & 4.7 & 32.7 & 2 & 7 & 12 & 193 & 3 & $8+$ & 8 & 14 & 14 & 7 & $2+5$ \\
\hline FUNED 2958 & $?$ & $75+$ & - & 4.2 & - & - & - & - & $67+$ & - & - & - & 14 & 14 & 7 & $2+5$ \\
\hline FUNED 2959 & $\mathrm{~F}$ & 162 & $8+$ & 4.4 & 36.8 & 2 & 6 & 14 & 192 & 3 & $8+$ & 8 & 12 & 14 & 6 & 2 \\
\hline FUNED 2960 & $?$ & $101+$ & - & 4.4 & - & - & - & - & $139+$ & - & - & - & 13 & 14 & 8 & $2+5$ \\
\hline
\end{tabular}

\# Postmalar row is absent in FUNED 2940 and FUNED 2949, because their malars are longer than in other specimens of the type series, apparently fused with what would be the first postmalar of each side.

2955, FUNED 2959, and of both sides in FUNED 2948, FUNED 2949, FUNED 2952, FUNED 2953 and FUNED 2960; in these specimens the temporal contacts the postocular dorsally, third supralabial ventro-anteriorly, postsupralabial ventro-posteriorly, and the first body annulus dorso-posteriorly. Additionally, FUNED 2955 has the right temporal fused with the first body annulus. FUNED 2947 and FUNED 2951 have an additional small pair of shields between prefrontals and frontals, apparently formed by the division of the anterior portion of frontals. In FUNED 2947 the additional pair is half the length of frontals. In FUNED 2951 the additional pair has about $1 / 4$ of frontal length.

Distribution. The new species is known only for the type-locality, in semi-deciduous seasonal forests of Conceição do Mato Dentro, Minas Gerais, Brazil, a region inside the Espinhaço Biosphere Reserve (UNESCO 2011) (Fig. 2).

Etymology. The specific name of the new species is a transliteration of the Greek $\mu \varepsilon \tau \alpha \lambda \lambda$ ovpyos (metalloyrgos), meaning "miner" (Liddle and Scott 1996). It is here used as an adjective that agrees in gender with the generic name. The name refers to the fossorial habits of amphisbaenians, which use 
the head to dig underground tunnels like a miner. Paradoxically, this new "mining reptile" was found in the area where a slurry pipeline is being installed. "Miner" is also the translation of the Portuguese words "mineiro" and "mineira", masculine and feminine adjectives referring to native inhabitants of the state of Minas Gerais, where the new species was discovered.

\section{DISCUSSION}

The Espinhaço Mountain Range in eastern Brazil is a large Precambrian orogenic belt extending over $1000 \mathrm{~km}$ in the North-South direction from the state of Bahia to the state of Minas Gerais, with elevations reaching 2000 meters (Leite et al. 2008, UNESCO 2011). In its center-south portion, the Espinhaço is at the transition zone between the Cerrado and the Atlantic Forest (UNESCO 2011). This mountain range is considered one of the most important centers of endemism of Brazilian biodiversity (Silva et al. 2008).

The southern region of the Espinhaço Mountain Range is under several human activities impacting natural environments, such as agriculture, livestock, and mining (Drummond et al. 2005). The type-locality of Amphisbaena metallurga sp. nov. was directly impacted by the installation of a slurry pipeline. However, including this species in any category of conservation threat would be premature, since other fragments of semi-deciduous seasonal forests are still present close to the typelocality. Therefore, we suggest the inclusion of A. metallurga sp. nov. in IUCN's Data Deficient category at global, national and regional levels.

Based on the current knowledge of geographic distribution, five other amphisbaenian species occur in southern Espinhaço: A. alba, A. dubia, A. infraorbitale, A. microcephala and $A$. vermicularis (Gans and Amdur 1966, Gans 1971a, Perez and Ribeiro 2008, HCC pers. obs.). A. metallurga sp. nov. can be easily distinguished from $A$. alba (characters inside parentheses) by having fewer precloacal pores (4-10) and midbody annuli (198-
248), tail with autotomy annulus (non autotomic tail), and fewer dorsal and ventral segments (30-42 / 35-46) (Vanzolini 2002). From A. dubia (characters inside parentheses) A. metallurga sp. nov. is distinguished by having fewer midbody annuli (211-231), longer tail with autotomy annulus (13-18 caudal annuli without autotomy), and third infralabial as long as the third supralabial (third infralabial two times longer than third supralabial) (Table SI, Gans 1964a). The new species can be distinguished from $A$. vermicularis (characters inside parentheses) by having fewer precloacal pores (4) and midbody annuli (211-254), and fewer dorsal and ventral segments (18-26 / 18-25) (Gans and Amdur 1966, Vanzolini 2002). Finally, it can be distinguished from $A$. infraorbitale and $A$. microcephala by the head shape, which is shovelshaped in the last two species.

Morphological similarities among Amphisbaena metallurga sp. nov., A. darwinii, A. heterozonata, A. prunicolor, A. silvestrii and A. trachura would suggest a close phylogenetic relationship despite their current distributions (Gans 1966, Perez et al. 2012, Teixeira et al. 2014). However, considering that some morphological characters of amphisbaenids are shared by convergence (Mott and Vieites 2009) it is premature to assume if similarities among the above cited species represent synapomorphies instead of convergences.

\section{ACKNOWLEDGMENTS}

We thank Giselle A. Cotta for allowing access to specimens under her care; Paulo C.A. Garcia for allowing the use of the stereomicroscope with photographic equipment at the Laboratório de Herpetologia, Universidade Federal de Minas Gerais; Bárbara F. Zaidan for photographs of the holotype; Samuel C. Gomides for aiding with specimens from UFMG; Daniel Loebmann, Miguel T. Rodrigues and Husssam Zaher for allowing access to specimens under their care; three anonymous reviewers for comments on improving 
the manuscript; and Tim Williams for etymology suggestions. HCC thanks the staff at Instituto de Ciências Biológicas at Universidade Federal de Viçosa - Campus Florestal, for access to facilities.

\section{RESUMO}

Uma nova espécie de Amphisbaena é descrita de uma floresta semidecidual em Conceição do Mato Dentro, sul da Cadeia do Espinhaço, Minas Gerais, Brasil. A seguinte combinação de caracteres permite diagnosticar a nova espécie das demais congêneres: cabeça arredondada; dois ou três poros pré-cloacais dispostos em sequência; 190-199 annuli corporais; 2-3 annuli laterais; 23-25 annuli caudais; plano de autotomia nos annuli caudais 7-9; 12-14 segmentos dorsais no annulus do meio do corpo; 14-16 segmentos ventrais no annulus do meio do corpo; três supralabiais; três infralabiais; fileira pósmalar presente ou ausente; dorso marrom-claro, com suturas intersegmentares creme; ventre creme. Até o momento a nova espécie é conhecida apenas para a Cadeia do Espinhaço, ressaltando a importância de ações de conservação para essas montanhas.

Palavras-chave: Minas Gerais, taxonomia, Amphisbaenia, réptil fossorial.

\section{REFERENCES}

CONRAD JL. 2008. Phylogeny and systematics of Squamata (Reptilia) based on morphology. Bull Am Mus Nat Hist 310: 1-182.

COSTA HC AND BÉRNILS RS. 2014. Répteis brasileiros: Lista de espécies. Herpetol Bras 3: 74-84.

DRUMmond GM, Martins CS, Machado ABM, SEBAio FA AND ANTONINI Y. 2005. Biodiversidade em Minas Gerais: Um Atlas para a Conservação. Belo Horizonte: Fundação Biodiversitas, $122 \mathrm{p}$.

DumÉRIL AMC AND BIBRon G. 1839. Erpétologie Générale ou Histoire Naturelle Complète des Reptiles. Tome Cinquiéme. Paris: Librairie Encyclopédique de Roret, $854-855 \mathrm{p}$.

GANS C. 1962. Redefinition and Description of the Brazilian Reptiles Amphisbaena silvestrii Boulenger and A. neglecta Dunn and Piatt. Copeia 1962: 164-170.

GANS C. 1963. Notes on Amphisbaenids (Amphisbaenia, Reptilia). 7. Redescription and Redefinition of Amphisbaena mitchelli Procter and Amphisbaena slevini Schmidt from the Middle and Lower Amazon, Brazil. Am Mus Novit 2127: 1-22.
GANS C. 1964a. Redescription of Amphisbaena dubia Müller (Amphisbaenia: Reptilia). Brevivora 205: 1-11.

GANS C. 1964b. New Records of Amphisbaena silvestrii Boulenger, and the Description of a New Two-Pored Species from the Northern Chaco. Copeia 1964: 553-561.

GANS C. 1964c. Amphisbaena mitchelli Procter Recorded from Belém, Pará, Brazil. Herpetologica 20: 192-194.

GANS C. 1964d. On the South American species of Amphisbaena with a vertically keeled tail (Amphisbaenia: Reptilia). Notes on amphisbaenids. 15. Senckenberg Biol 45: 387-416.

GANS C. 1965. Notes on amphisbaenids. 17. Redescription and discussion of Amphisbaena angustifrons Cope and A. camura Cope, large amphisbaenids of southern South America (Amphisbaenia: Reptilia). Am Mus Novit 2225: 1-32.

GANS C. 1966. Studies on amphisbaenids (Amphisbaenia: Reptilia) 3. The small species from southern South America commonly identified as Amphisbaena darwini. Bull Am Mus Nat Hist 134: 185-260.

GANS C. 1971a. Studies on Amphisbaenians (Amphisbaenia, Reptilia). 4. A Review of the Amphisbaenid genus Leposternon. Bull Am Mus Nat Hist 144: 379-464.

GANS C. 1971b. Redescription of Three Monotypic Genera of Amphisbaenians From South America: Aulura Barbour, Bronia Gray, and Mesobaena Mertens. Am Mus Novit 2475: 1-32.

GANS CAND ALEXANDER AA. 1962. Studies on the amphisbaenids (Amphisbaenia; Reptilia). 2. On the amphisbaenids of the Antilles. Bull Mus Comp Zool 128: 65-158.

GANS C AND AMDUR MA. 1966. Redescription of Amphisbaena vermicularis Wagler, with comments on ots range and synonymy (Amphisbaenia: Reptilia). P CalifA Sci 33: 69-90.

Gauthier JA, KeARney M, Maisano JA, Rieppel O AND BEHIKE ADB. 2012. Assembling the Squamate Tree of Life: perspectives from the phenotype and the fossil record. Bull Peabody Mus Nat Hist 53: 3-308.

KEARNEY M. 2003. Systematics of the Amphisbaenia (Lepidosauria: Squamata) based on morphological evidence from recent and fossils forms. Herpetol Monogr 17: 1-74.

KEARNEY M AND STUART BL. 2004. Repeated evolution of limblessness and digging heads in worm lizards revealed by DNA from old bones. Proc R Soc B 271: 1677-1683.

LEITE FSF, JuNCÁ FA AND ETEROVICK PC. 2008. Status do conhecimento, endemismo e conservação de anfíbios anuros da Cadeia do Espinhaço, Brasil. Megadiversidade 4: 158-176.

LIDDLE HG AND SCOTT R. 1996. A Greek-English Lexicon. Ninth Edition with revisions by JONES HS AND MCKENZIE R. Oxford: Oxford University Press, 804 p.

MACEY JR, PAPENFuss TJ, Kuehl JV, FourCADE HM AND BOORE JL. 2004. Phylogenetic relationships among amphisbaenian reptiles based on complete mitochondrial genomic sequences. Mol Phylogenet Evol 33: 22-31.

Montero R. 1996. Amphisbaena bolivica Mertens 1929, nueva combinación (Squamata: Amphisbaenia). Cuad Herpetol 9: 75-84.

Montero R And CÉSPedez J. 2002. New Two-Pored Amphisbaena (Squamata: Amphisbaenidae) from Argentina. Copeia 2002: 792-797. 
MotT T AND ViEITES DR. 2009. Molecular phylogenetics reveals extreme morphological homoplasy in Brazilian worm lizards challenging current taxonomy. Mol Phylogenet Evol 51: 190-200.

MotT T, CARVAlHO-NeTO CS AND CARVAlHo FilHo KS. 2011 Amphisbaena miringoera Vanzolini, 1971 (Squamata: Amphisbaenidae): New state record. Check List 7: 594-595.

PEREZ R AND RIBEIRO SLB. 2008. Reptilia, Squamata, Amphisbaenidae, Leposternon spp.: Distribution extension, new state record, and geographic distribution map. Check List 4: 291-294.

Perez R, Ribeiro S AND Borges-Martins M. 2012. Reappraisal of the taxonomic status of Amphisbaena prunicolor (Cope 1885) and Amphisbaena albocingulata Boettger 1885 (Amphisbaenia: Amphisbaenidae). Zootaxa 3550: 1-25.

Peters JA AND Donoso-Barros R. 1970. Catalogue of the Neotropical Squamata Part II. Lizards and Amphisbaenians. US Nat Mus Bull 297: 1-293.

PIANKA ER AND VITT LJ. 2003. Lizards: Windows to the Evolution of Diversity. Berkeley/Los Angeles/London: University of California Press, 333 p.

PINNA PH, MENDONÇA AF, BOCCHIGLIERI A AND FERNANDES DS. 2010. A new two-pored Amphisbaena Linnaeus from the endangered Brazilian Cerrado biome (Squamata: Amphisbaenidae). Zootaxa 2569: 44-54.

Pinna PH, MendonçA AF, Bocchiglieri A And FERnandes DS. 2014. A New Species of Amphisbaena Linnaeus, 1758 from a Cerrado Region in Bahia, Northeastern Brazil (Squamata: Amphisbaenidae). Herpetologica 70: 339-349.

Porto M, SOARES M AND CARAMASCHI U. 2000. A new species of Leposternon (Amphisbaenia, Amphisbaenidae) from Minas Gerais, Brazil, with a key to the species of the genus (Amphisbaenia, Amphisbaenidae). Bol Mus Nac 412: 1-10.

PYron RA, BurbrinK FT AND WiENS JJ. 2013. A phylogeny and revised classification of Squamata, including 4161 species of lizards and snakes. BMC Evol Biol 13: 1-53.

Ribeiro S, Nogueira C, Cintra CED, SiLva NJ AND Zaher H. 2012. [dated 2011] Description of a New Pored Leposternon (Squamata, Amphisbaenidae) from the Brazilian Cerrado. South Am J Herpetol 6: 177-188.

RibeIRo S, VAZ-SILVA W AND SANTOS AP Jr. 2008. New pored Leposternon (Squamata, Amphisbaenia) from Brazilian Cerrado. Zootaxa 1930: 18-38.

Roberto IJ, Brito LBM AND ÁviLA RW. 2014. A new sixpored Amphisbaena (Squamata: Amphisbaenidae) from the coastal zone of northeast Brazil. Zootaxa 3753: 167-176.

Silva JA, Machado RB, AzEVEdo AA, Drumond GM, FONSECA RL, GOUlART MF, MORAES JÚNIOR EA, MARTINS CS AND RAMOS NETO MB. 2008. Identificação de áreas insubstituíveis para conservação da Cadeia do Espinhaço, estados de Minas Gerais e Bahia. Megadiversidade 4: 248-270.

STRÜSSMAN C AND CARVALHO MA. 2001. Two new species of Cercolophia Vanzolini 1992 from the state of Mato Grosso, western Brazil (Reptilia, Amphisbaenia, Amphisbaenidae). Boll Mus Regionale Sci Nat Torino 18: 487-505.
STRÜSSMANN C AND MOTT T. 2009. Sympatric amphisbaenids from Manso Dam region, Mato Grosso State, Western Brazil, with the description of a new two-pored species of Amphisbaena (Squamata, Amphisbaenidae). Stud Neotrop Fauna Environ 44: 37-46.

Stimson AF. 1972. A new species of Anops from Mato Grosso, Brazil (Reptilia: Amphisbaenia). Bull Br Mus Nat Hist Zool 24: 205-212.

TeiXeira M, Dal Vechio F, Mollo Neto A and Rodrigues MT. 2014. A New Two-Pored Amphisbaena Linnaeus, 1758, from Western Amazonia, Brazil (Amphisbaenia: Reptilia). South Am J Herpetol 9: 62-74.

UetZ P AND HoŠEK J. 2014. The Reptile Database, http://www. reptile-database.org [accessed 09.V.2014].

UNESCO. 2011. Espinhaço Range. UNESCO MAB Biosphere Reserves Directory, http://www.unesco.org/mabdb/br/ brdir/directory/biores.asp mode $=$ all $\&$ code $=$ BRA +06 [accessed 22.I.2014].

VANZOLINI PE. 1996. On slender species of Amphisbaena, with the description of A new one from Northeastern Brasil (Reptilia, Amphisbaenia). Pap Avulsos Zool 39: 293-305.

VANZOLINI PE. 1997. The silvestrii species group of Amphisbaena, with the description of two new Brasilian species (Reptilia: Amphisbaenia). Pap Avulsos Zool 40 65-85.

VANZOLINI PE. 2002. An aid to the identification of the south American species of Amphisbaena (Squamata, Amphisbaenidae). Pap Avulsos Zool 42: 351-362.

Vidal N, Azvolinsky A, CRUaud C AND Hedges SB 2008. Origin of tropical American burrowing reptiles by transatlantic rafting. Biol Lett 4: 115-118.

\section{APPENDIX}

Additional specimens examined, from CHFURG, MZUSP, and MTR. Toponyms are cited in descending order (COUNTRY, State/Province, City/County, Locality).

Amphisbaena alba: BRAZIL: São Paulo: Teodoro Sampaio, Parque Estadual do Morro do Diabo: MZUSP 96810.

Amphisbaena anaemariae: BRAZIL: Goiás: Campinaçu: MZUSP 103743; Luiziânia: MTR 11453, MTR 115454; São Salvador do Tocantins, UHE São Salvador: MZUSP 99394; UHE Cana Brava: MZUSP 97217; UHE Serra da Mesa: MZUSP 97047, MZUSP 97171.

Amphisbaema caiari: BRAZIL: Rondônia: Porto Velho: MZUSP 101727 (holotype), MZUSP 101695 
101697, MZUSP 101715-101718, MZUSP 101720, MZUSP 101722-101726, MZUSP 101728-101733, MZUSP 102226-102236, MZUSP 102238-102263 (paratypes).

Amphisbaema carli: BRAZIL: Bahia: São Desidério: MZUSP 100658.

Amphisbaema cunhai: BRAZIL: Rondônia: Porto Velho: MZUSP 101719, MZUSP 101721, MZUSP 101734, MZUSP 102237.

Amphisbaena darwinii: BRAZIL: Santa Catarina: Lauro Müller, Novo Horizonte: MZUSP 21467; Rio Grande do Sul: Rio Grande, ESEC Taim: CHFURG 1072, CHFURG 1462, CHFURG 1528, CHFURG 1551; Fazenda Votorantin: CHFURG 39; Parque Marinha: CHFURG 1446; Senandes: CHFURG 2541. URUGUAY: Montevideo: Puntas de Manga: MZUSP 82343-82344.

Amphisbaena dubia: BRAZIL: Minas Gerais: Poços de Caldas: MZUSP 13727, MZUSP 93983; São Paulo: Aurora: MZUSP 6439; Campos do Jordão: MZUSP 2527; Cascata: MZUSP 6432; Cotia: MZUSP 100372; Diadema: MZUSP 95082; Embu: MZUSP 6461; Guarulhos: MZUSP 87605; Mairinque: MZUSP 6433; Mogi da Cruzes: MZUSP 44696; Santana de Parnaíba: MZUSP 77048; Santo Amaro: MZUSP 60424; São Bernardo do Campo: MZUSP 11870; São José do Rio Preto: MZUSP 6442; São Manoel: MZUSP 6520; São Paulo: MZUSP 77051, MZUSP 83031, MZUSP 89663; Pirituba: MZUSP 91505.

Amphisbaena fuliginosa: BRAZIL: Rondônia: Porto Velho: MZUSP 102785.

Amphisbaena heterozonata: ARGENTINA: Buenos Aires: La Plata: MZUSP 59215, MZUSP 59217; Córdoba: Pampa de Achala: MZUSP 82358; Tucumán: San Miguel de Tucumán: MZUSP 13744-13745.

Amphisbaena hogei: BRAZIL: São Paulo: Caucaia do Alto: MTR 15328.
Amphisbaena leeseri: BRAZIL: Mato Grosso: Aquidauana: MZUSP 82539-82541; Guia Lopes da Lagoa: MZUSP 73313.

Amphisbaena mitchelli: BRAZIL: Pará: Belém: MZUSP 7140; Juruá, Rio Xingu: MZUSP 67714.

Amphisbaena polystega: BRAZIL: Tocantins: UHE Luís Eduardo Magalhães: MTR MTR 8640, MTR 8824-8826, MTR 8689, MTR 8641, MTR 8793, MTR 8806, MTR 8804.

Amphisbaena ridleyi: BRAZIL: Pernambuco: Fernando de Noronha: CHFURG 2229.

Amphisbaena silvestrii: BRAZIL: São Paulo: Santa Rita: MZUSP 100897; Goiás: Aruanã: MZUSP 2525; Gurupi: MZUSP 57037; Parque Nacional das Emas: MZUSP 87733; Mato Grosso: Alto Araguaia, Fazenda Granada: MZUSP 99258; Barra do Tapirapés: MZUSP 10069, MZUSP 9010; Canarana, Fazenda Peixe-Boi: MZUSP 88864; Claudia, Fazenda Iracema: MZUSP 81778; Garapu, Alto Xingu: MZUSP 3286; Jacaré, Alto Xingu: MZUSP 6412-6413; Porto Velho, Rio Tapirapés: MZUSP 9743, MZUSP 9757; UHE Guaporé: MZUSP 97884; Utiarití: MZUSP 36857; Xavantina: MZUSP 3367; Mato Grosso do Sul: Fazenda Bela Vista, Rio Paraguai: MZUSP 62398; Parque Estadual Nascentes do Taquarí: MZUSP 88659.

Amphisbaena slevini: BRAZIL: Amazonas: Manaus: MZUSP 10913; Reserva INPA-WWF: MZUSP 60905-60906, MZUSP 66148.

Amphisbaena trachura: BRAZIL: Rio Grande do Sul: Rio Grande: CHFURG 2377; Corredor do Senandes: CHFURG 811; ESEC Taim: CHFURG 1406, CHFURG 1417, CHFURG 1526; Fazenda Votorantin: CHFURG 38; Praia do Cassino: CHFURG 1453, CHFURG 1454.

\section{SUPPLEMENTARY MATERIAL}

Table SI - Morphological diagnostic characters of two-pored and three-pored South American Amphisbaena species. 
